\title{
DETERMINING MARKETING STRATEGY AT LPP TVRI RIAU USING SWOT ANALYSIS METHOD
}

\author{
Muhammad Rizki ${ }^{1 *}$, Afdal Ghifari ${ }^{2}$, Wang Ling Hui ${ }^{3}$, Ekie Gilang Permata ${ }^{4}$, Mhd. \\ Dany Siregar $^{5}$, Muhammad Isnaini Hadiyul Umam ${ }^{6}$, Harpito $^{7}$ \\ Univeritas Islam Negeri Sultan Syarif Kasim Riau ${ }^{1,4,5,6,7}$, Hochschule Bremen ${ }^{2}$, National Taiwan \\ University of Science and Technology ${ }^{3}$

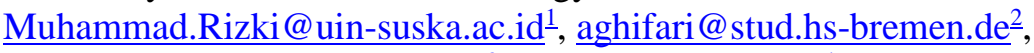 \\ m10101203@mail.ntust.edu.tw ${ }^{3}$, ekiegp@yahoo.com ${ }^{4}$, mhddanny@ gmail.com $^{5}$, \\ muhammad.isnaini@uin-suska.ac.id ${ }^{6}$, harpito@uin-suska.ac.id ${ }^{7}$
}

Received : 06 October 2021, Revised: 26 December 2021, Accepted : 26 December 2021

*Coresponding Author

\begin{abstract}
The purpose of this study was to use the SWOT approach to assess LPP TVRI Riau's marketing strategy. The focus of this research is to figure out internal and external factors in the SWOT analysis. This study used descriptive quantitative method. Sampling was performed by using probability sampling method with a total of 400 respondents from 6,394,087 populations from Riau Province. The questionnaire was designed by determining the level of importance and assessing the current conditions. Based on the results of the SWOT compilation, there are 5 strengths, 5 weaknesses, 4 opportunities, and 5 threats. Furthermore, weighting, rating, and scores are carried out at the IFAS and EFAS stages, for the weighting assessment carried out on the company side. The company's position is in quadrant II, which means that the company has more dominant strengths and threats, so that the company should support the diversification strategy policy. So that the SWOT matrix mapping can be done to produce four strategic policy alternatives, namely SO, ST, WO, WT.
\end{abstract}

Keywords: Marketing Strategy, SWOT Analysis, IFAS, EFAS .

\section{Introduction}

Television is one of the electronic mass media that cannot be separated by the community and can be well received. Television is also one of the mass media that is very influential on society because it has provided many benefits in the form of information and entertainment. The presence of mass media in the community is very supportive of the creation of an information society that tends to need information, therefore television parameters are competing to provide as much information as possible to the public (Fatema, K., \& Lariscy, J. T., 2020).

There are 14 commercial television stations and one state-owned television station in Indonesia. RCTI, GTV, INDOSIAR, INEWS, KOMPAS TV, METRO TV, MNC TV, NET TV, RTV, SCTV, TRANS7, TRANS TV, and TV ONE are among the thirteen private television channels. TVRI is directed to be able to compete with other TVs with thirteen private television stations(Rangkuti, et. al., 2020).

TVRI (Televisi Republik Indonesia) is Indonesia's primary public television network. The Radio Republic of Indonesia has designated TVRI as a Public Broadcasting Institution, as defined by Law Number 32 of 2002 on Broadcasting. TVRI, Indonesia's first television network, began airing on August 24, 1962. Until 1989, when the first commercial television station was founded, TVRI monopolized television transmission in Indonesia(Hamidah, et. al., 2021). With analog and broadcast systems, TVRI is presently transmitting throughout Indonesian territory. digital. TVRI operates three national television channels, two of which are exclusively digital, as well as 30 regional television stations, all of which are backed by 361 transmission stations, including 120 digital transmission stations, across Indonesia's provinces. TVRI has had a long trip and plays an important part in the struggle and journey of the Indonesian people's life, therefore there is a lot of rivalry from non-government television(Sari, 2020; Janah, N., \& Mayesti, N., 2020). 
Table 1 - News Broadcasting Program Quality Indicator Index by Broadcasting Institution

\begin{tabular}{|c|c|c|c|c|c|c|c|c|c|c|c|c|c|}
\hline \multirow{2}{*}{$\begin{array}{l}\text { Quality } \\
\text { Factors }\end{array}$} & \multicolumn{13}{|c|}{ Broadcasting Institution } \\
\hline & RCTI & GTV & Indosiar & iNews & $\begin{array}{l}\text { Kompas } \\
\text { TV }\end{array}$ & $\begin{array}{l}\text { Metro } \\
\text { TV }\end{array}$ & $\begin{array}{l}\text { MNC } \\
\text { TV }\end{array}$ & $\begin{array}{l}\text { NET } \\
\text { TV }\end{array}$ & RTV & SCTV & $\begin{array}{l}\text { TRANS } \\
\text { TV }\end{array}$ & $\begin{array}{l}\text { TV } \\
\text { ONE }\end{array}$ & TVRI \\
\hline Factuality & 3.23 & 3.09 & 3.14 & 3.18 & 3.55 & 3.05 & 3.09 & 3.36 & 3.23 & 3.45 & 3.27 & 3.32 & 3.64 \\
\hline Factuality & 3.09 & 3.09 & 3.30 & 3.22 & 3.61 & 3.09 & 3.00 & 3.26 & 3.17 & 3.43 & 3.35 & 3.35 & 3.57 \\
\hline Neutral & 3.00 & 2.90 & 3.14 & 3.14 & 3.38 & 2.62 & 3.05 & 3.24 & 3.14 & 3.29 & 3.29 & 3.38 & 3.48 \\
\hline $\begin{array}{l}\text { Public } \\
\text { Interest }\end{array}$ & 3.10 & 3.03 & 3.19 & 3.18 & 3.51 & 2.92 & 3.26 & 3.19 & 3.18 & 3.35 & 3.59 & 3.20 & 3.48 \\
\hline $\begin{array}{l}\text { Humanity } \\
\text { Value }\end{array}$ & 3.00 & 3.00 & 3.17 & 3.13 & 3.43 & 3.30 & 2.96 & 3.04 & 3.09 & 3.22 & 3.13 & 3.30 & 3.35 \\
\hline $\begin{array}{l}\text { Average } \\
\text { Index }\end{array}$ & 3.08 & 3.02 & 3.19 & 3.17 & 3.50 & 2.99 & 3.07 & 3.22 & 3.16 & 3.35 & 3.33 & 3.21 & 3.50 \\
\hline
\end{tabular}

According to the information presented above, TVRI must develop a plan to compete with rivals who have a strong potential to compete with TVRI, and TVRI must be obliged to develop competitive advantages. In general, all companies must be able to adopt an acceptable strategy in order for organizational rivalry to succeed, and for the organization to expand and develop sustainably with the aid of internal and external SWOT analysis techniques(Elavarasan, et. al., 2020; Longhurst, et. al., 2020).

SWOT analysis in a company aims to provide a guide so that the company becomes more focused, so that the SWOT analysis can later be used as a comparison of thoughts from various points of view, both in terms of strengths and weaknesses as well as opportunities and threats that may arise in the future. SWOT analysis is a strategy-making tool that systematically evaluates and identifies numerous elements in order to develop a company-based strategy. based on a logic that maximizes strengths and opportunities, while minimizing weaknesses and threats in a highstakes market(Li, et. al., 2020; Bonfante, et. al., 2021).

Based on observations and interviews conducted at LPP TVRI Riau, TVRI does not yet have standards or provisions in looking for opportunities and threats to TVRI based on internal and external factors, so the researchers decided to conduct a decision strategy at the TVRI Riau branch using SWOT analysis and at the same time looking for matches whether the analysis SWOT can be applied to TVRI.

\section{Literature Review}

Marketing is a set of activities carried out by a group of people in order to meet their needs and desires through an exchange process. Marketing is a broad set of activities aimed at identifying, pricing, promoting, and distributing goods and services that meet the needs of current and potential customers. As a result, marketing activities can be defined as human activities that occur in the context of a market(Kayumovich, et. al., 2020).

Marketing General is a set of business operations that aims to plan, price, advertise, and distribute items in order to meet customer needs and reach target markets while also meeting the company's objectives. Marketing also refers to satisfying customer requirements and achieving a company's objectives in order to generate revenues and ensure the company's existence (Huang, M. H., \& Rust, R. T., 2021).

According to Li, et. al., 2021, marketing strategy is "the marketing rationale by which the firm expects to generate value, the consumers who will service it (segmentation and targeting), and the manner in which the company will serve it" (differentiation and positioning). The firm first analyzes the whole market, then splits it into smaller groups, chooses the most promising sectors, and concentrates on customer service and happiness within these segments.

SWOT analysis is a strategy formulation technique that systematically evaluates and identifies numerous elements in order to develop a corporate plan based on logic that maximizes strengths and opportunities while minimizing weaknesses and threats. This procedure entails establishing the precise objectives of the hypothetical firm or project, as well as the internal and external elements that support or hinder the achievement of these objectives(Voukkali, I., \& Zorpas, A. A., 2022). 


\section{STRENGTHS}

Owner has experience in food service

Owner has many connections in the industry

Owner willing to take an educated risk

Owner willing to work long hours

Must buy (not lease or rent) all equipment

\section{WEAKNESSES}

Owner has never run a business

Owner unsure of tax and accounting practices

Help from family is not forthcoming

Must buy (not lease or rent) all equipment

\section{OPPORTUNITIES}

Local area has lots of tourists

No portable ice cream vans being used

Potential market for catering to parties/ functions

\section{External factors \\ THREATS \\ Several restaurants offer take-away ice cream service \\ Local government frowns on small businesses \\ The ice cream market is highly seasonal}

Fig. 1. SWOT Analysis

SWOT analysis can be applied. by analyzing and sorting out various things that affect the four factors, then applying them in a SWOT matrix image, where the application is. how strengths are able to take advantage of existing opportunities, how to overcome weaknesses that prevent advantages from existing opportunities, then how strengths are able to deal with threats that exist, and lastly is how to overcome the weaknesses that are able to make threats become real or create a new threat(Jiskani, et. al., 2020).

Internal analysis includes 1) Analysis of Strength, strength is situation or condition that is the strength of the company. Strength is an internal factor that supports the company in achieving its goals. Supporting factors can be in the form of technology, resources, expertise, marketing strength, and customer base owned or other advantages that may be obtained due to financial resources, image, market advantages, and good relations between buyers and suppliers. 2) Analysis of Weaknesses, weaknesses are activities that are not going well, or resources needed by the company but not owned by the company. Weakness is sometimes easier to see than a strength, but there are several things that make the weakness not given the right solution because the existing strengths are not maximized. Weaknesses are internal factors that hinder the company in achieving its goals. Inhibiting factors can be in the form of incomplete facilities, lack of financial resources, ability to manage, marketing expertise, and company image(Irfan, et. al., 2020).

External Analysis 1) Opportunity Analysis, opportunity is a positive factor that arises from the environment and provides opportunities for companies to take advantage of them. Opportunity is a supporting external factor. company in achieving its goals. External factors that support the achievement of goals can be in the form of policy changes, technological changes, economic developments and development of supplier and buyer relationships. 2) Threat Analysis, threat is a negative factor of. environment that provides obstacles to the development or operation of a company. Threat. this is something that sometimes always. missed because many want to try to controversy or go against the flow. However, the company wilted more before growing. Threats are. external factors that hinder the company in achieving its goals. External factors that hinder the company can be in the form of the entry of new competitors, slow market growth, increasing gaining power of the main suppliers and buyers, changes in technology and new policies(Jetoo, S., \& Lahtinen, V., 2021).

SWOT analysis was used. to see the strengths, weaknesses, opportunities and threats that will be faced by the company. By looking at the strengths and developing strengths. It can be ascertained that the company will be more advanced than existing competitors. Likewise, the weaknesses they have must be corrected so that the company can continue to exist. There must be opportunities. be utilized as well as possible by the company so that sales volume can increase. 
And the threat that will be faced by the company suggests that the SWOT analysis. is an evaluation of the overall strengths, weaknesses, opportunities and threats called SWOT analysis(BlancoGutiérrez, et. al., 2020).

\section{Research Methods}

Data collection was carried out as a reference in conducting research. Collecting data in the form of primary data and secondary data as well as reviewing data collection techniques used by researchers.

\section{Data Source}

The data sources needed in this study consist of primary and secondary data which will be described as follows

Primary data

Primary data is data that is directly obtained from the main source by means of observation at LPP TVRI Riau and interviews with the company. In addition to observations and interviews, researchers also distributed questionnaires to obtain external and internal assessments.

Secondary Data

Secondary data is data that indirectly provides information to data collectors such as documents. In this study, secondary data in the form of emission factor data were obtained from relevant journals and data from the internet such as wikipedia and the official website of the Indonesian Broadcasting Commission (KPI).

2. Data Collection Techniques

The data collection techniques that the researchers did consist of 3 techniques, namely:

\section{Observation}

Observation is a technique or method of collecting data by observing ongoing activities. in this study, the researcher as a non-participating observation means that the researcher only observes ongoing activities without participating in activities at LPP TVRI.

Interview

This study uses free guided interviews, meaning that the interviews are open but based on the direction of the researcher. Interviews were conducted with the company.

Questionnaire

Questionnaire is an information gathering technique that allows to study the attitudes, beliefs, behaviors, and characteristics of several people. In this study, researchers distributed questionnaires to determine the external and internal values of the company.

3. Data Processing

After the data is obtained, the next step is to carry out data processing. The following are the stages of data processing to determine the strengths, weaknesses, opportunities and threats (SWOT) at LPP TVRI(Akdu, 2020; Dulić, et. al., 2020).

SWOT Internal and External Assessment

The first time the data processing is done is recapitulation of data from the questionnaire to get the value of weights and ratings on the internal and external data of LPP TVRI.

IFAS and EFAS Matrix

After getting the internal and external scores from the questionnaire, the next step is the IFE and EFE Matrix. IFE Matrix. used to find out how big the role of the internal factors contained in the company which consists of strengths and weaknesses which are calculated based on ratings and weights. EFE Matrix. used to determine the company's external factors consisting of opportunities and threats calculated based on weights.

SWOT Matrix

Next do the steps. matching to formulate a strategy based on the results of the analysis and identification of the company's internal and external environmental conditions that have been collected based on. strengths, weaknesses, opportunities and threats obtained through internal and external audits. 


\section{Results and Discussions}

The indicators on internal factors and external factors are as follows:

Strength

1. Broad broadcast coverage power

2. Strong network

3. Public Interest

4. Human Values

5. Depth of information

Weakness

1. Network frequency has not yet reached remote villages

2. Picture and sound quality is not good

3. Impressions on TVRI are less interesting and not varied

4. The ability of the presenter

5. Skilled and trained human resources

Opportunities

1. The number of internet and social media users

2. The demands of community events that need TV shows that are different from others

3. There are still few educational programs on television

4. More sophisticated equipment technology

Threats

1. Many private TVs are getting creative

2. The increasing number of online entertainment media

3. Potential competitors emerge in other product areas

4. Difficult broadcast licensing in various TV shows by KPI

5. The number of competitors for events in the same segmentation is increasing

Internal Strategy Factor Matrix (IFAS)

After the factors of a company's internal strategy are identified, an IFAS table is compiled to formulate the factors of the internal strategy in the framework of strengths and weaknesses. Furthermore, the calculation method is carried out to determine the value of weight, rating, and score. In the IFAS matrix, the value of the result of reducing Strength and Weakness is 1.017(Landmann, et. al., 2020).

Table 2 - Matrix IFAS

\begin{tabular}{|c|c|c|c|c|}
\hline $\mathrm{NO}$ & INTERNAL FACTORS & WEIGHT & RATING & SCORE \\
\hline \multicolumn{5}{|c|}{ STRENGHT } \\
\hline 1 & Broadcast Coverage & 0.2 & 3 & 0.6 \\
\hline 2 & Networking & 0.163 & 3 & 0.489 \\
\hline 3 & Public Interest & 0.2 & 3 & 0.6 \\
\hline 4 & Human Values & 0.218 & 3 & 0.654 \\
\hline 5 & Accurate Information & 0.218 & 3 & 0.654 \\
\hline \multicolumn{5}{|c|}{$\begin{array}{l}\text { Total Strenght } \\
\text { WEAKNESS }\end{array}$} \\
\hline 1 & $\begin{array}{l}\text { Network frequency has not yet reached remote } \\
\text { villages }\end{array}$ & 0.17 & 2 & 0.34 \\
\hline 2 & $\begin{array}{l}\text { Picture and sound quality is not good } \\
\text { Impressions on TVRI are less interesting and not }\end{array}$ & 0.19 & 2 & 0.38 \\
\hline 3 & varied & 0.19 & 2 & 0.38 \\
\hline 4 & Host ability & 0.23 & 2 & 0.46 \\
\hline 5 & Skilled and trained human resources & 0.21 & 2 & 0.42 \\
\hline \multicolumn{4}{|c|}{ Total Weakness } & 1.98 \\
\hline & $\mathbf{S}-\mathbf{W}$ & & & 1.017 \\
\hline
\end{tabular}


External Strategy Factor Matrix (EFAS)

The calculation performed on the EFAS matrix is not much like the calculation on the IFAS matrix, namely by reducing the number of opportunities and the number of threats, which is 0.03(Susanti, et. al., 2021).

Table 3 - Matrix EFAS

\begin{tabular}{|c|c|c|c|c|}
\hline NO & EXTERNAL FACTORS & WEIGHT & RATING & SCORE \\
\hline \multicolumn{5}{|c|}{ OPPORTUNITIES } \\
\hline 1 & The number of internet and social media users & 0.29 & 3 & 0.87 \\
\hline 2 & $\begin{array}{l}\text { The demands of community events that need a TV } \\
\text { show that is different from the others }\end{array}$ & 0.26 & 3 & 0.78 \\
\hline 3 & $\begin{array}{l}\text { There are still few educational programs on } \\
\text { television }\end{array}$ & 0.21 & 3 & 0.63 \\
\hline 4 & More sophisticated equipment technology & 0.21 & 3 & 0.63 \\
\hline & Total Opportunities & & & 2.91 \\
\hline \multicolumn{5}{|c|}{ THREATS } \\
\hline 1 & $\begin{array}{l}\text { Many private TVs are getting creative } \\
\text { The number of online entertainment media is }\end{array}$ & 0.16 & 3 & 0.48 \\
\hline 2 & $\begin{array}{l}\text { increasing } \\
\text { Potential competitors are emerging in other product }\end{array}$ & 0.21 & 3 & 0.63 \\
\hline 3 & areas & 0.21 & 3 & 0.63 \\
\hline 4 & $\begin{array}{l}\text { Difficult broadcast licensing in various TV shows } \\
\text { by KPI }\end{array}$ & 0.19 & 3 & 0.57 \\
\hline 5 & $\begin{array}{l}\text { The number of competitors for events in the same } \\
\text { segment is increasing }\end{array}$ & 0.21 & 3 & 0.63 \\
\hline \multicolumn{3}{|c|}{ Total Threats } & & 2.94 \\
\hline & $\mathbf{O}-\mathbf{T}$ & & & -0.03 \\
\hline
\end{tabular}

SWOT Quadrant

After getting the results from the IFAS and EFAS matrices, the next step is to determine the strategic position in the SWOT quadrant, as shown in the image below with a value ( $x=1.017$, $y=-0.03)($ Komari, et. al., 2020). The quadrants in the SWOT analysis are as follows: 


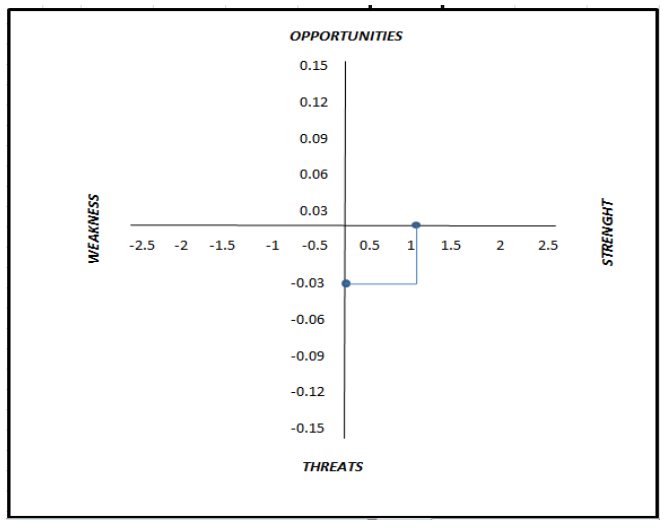

Fig. 2. SWOT QUADRANT

In the SWOT quadrant as shown above, it is in a quadrant II position where in this position the company supports a diversification strategy policy(Putri, et. al., 2020).

SWOT Matrix

Furthermore, to formulate alternative strategies at LPP TVRI Riau using the SWOT matrix, strategic alternatives are prepared based on the interaction of the company's internal and external factors to obtain a competitive strategy.

SO Strategy

1. Improve the quality of broadcast programs that are more interesting

2. Maintain and improve the quality of broadcast programs to retain viewers

3. Using brand image to attract viewers from newcomers

ST strategy

1. Strengthen the image that has been formed

2. Improving the quality of impressions and service quality

3. Create a program of events in accordance with the provisions

WO Strategy

1. Improve cost efficiency

2. Strive for the development and training of Human Resources (HR)).

3. Creating innovative new broadcast programs

4. Maximizing the introduction of broadcast programs through social media

WT Strategy

1. Establish a new business strategy that is more efficient and effective

2. Pay more attention to the quality and quality of service to viewers

3. Explore local potential (TVRI Riau) to create superior programs

\section{Conclusion}

Based on the weight and rating diagram of each element of the SWOT matrix, it can be seen that the company or agency of LPP TVRI Riau is currently in quadrant II. LPP TVRI Riau has internal coordinates: (total score of strength - total score of weakness): $2.997-1.98=1.017$. On External Coordinates: (total score of opportunities - total score of threats): $2.91-2.94=$ 0.03 . So the coordinates are at $(1.017 ;-0.03)$ so you can take advantage of the opportunities that exist. The strategy that must be applied in this position is to support a diversification strategy policy where the general strategy that can be carried out by the company is to use the company's strengths and threats to take every advantage that exists. The strategy that can be applied is a diversification strategy, namely by looking for new opportunities to increase the potential for the quality of the company

\section{References}

Akdu, U. (2020). Smart Tourism: Issues, Challenges and Opportunities. In The Emerald Handbook of ICT in Tourism and Hospitality. Emerald Publishing Limited. 
Blanco-Gutiérrez, I., Varela-Ortega, C., \& Manners, R. (2020). Evaluating animal-based foods and plant-based alternatives using multi-criteria and SWOT analyses. International Journal of Environmental Research and Public Health, 17(21), 7969.

Bonfante, M. C., Raspini, J. P., Fernandes, I. B., Fernandes, S., Campos, L. M., \& Alarcon, O. E. (2021). Achieving Sustainable Development Goals in rare earth magnets production: A review on state of the art and SWOT analysis. Renewable and Sustainable Energy Reviews, 137, 110616.

Dulić, J., Ljubojević, M., Savić, D., Ognjanov, V., Dulić, T., Barać, G., \& Milović, M. (2020). Implementation of SWOT analysis to evaluate conservation necessity and utilization of natural wealth: terrestrial orchids as a case study. Journal of Environmental Planning and Management, 63(12), 2265-2286.

Elavarasan, R. M., Afridhis, S., Vijayaraghavan, R. R., Subramaniam, U., \& Nurunnabi, M. (2020). SWOT analysis: A framework for comprehensive evaluation of drivers and barriers for renewable energy development in significant countries. Energy Reports, 6, $1838-1864$.

Fatema, K., \& Lariscy, J. T. (2020). Mass media exposure and maternal healthcare utilization in South Asia. SSM-Population Health, 11, 100614.

Hamidah, S., Afidah, N. N., Kurniawaty, I., Abdillah, H. T., \& Nugraha, R. H. (2021). Language style and local wisdom in The Travel Documentary Pesona Indonesia: Tondokku Kondosapata on TVRI as a medium for tourism promotion. In Promoting Creative Tourism: Current Issues in Tourism Research (pp. 9-16). Routledge.

Huang, M. H., \& Rust, R. T. (2021). A strategic framework for artificial intelligence in marketing. Journal of the Academy of Marketing Science, 49(1), 30-50.

Irfan, M., Hao, Y., Panjwani, M. K., Khan, D., Chandio, A. A., \& Li, H. (2020). Competitive assessment of South Asia's wind power industry: SWOT analysis and value chain combined model. Energy Strategy Reviews, 32, 100540.

Janah, N., \& Mayesti, N. (2020). Maturity Model Matrix of Information Governance in the Republic of Indonesia Public Television Broadcasting Institution. A Technical Note. Australasian Accounting, Business and Finance Journal, 14(1), 97-104.

Jetoo, S., \& Lahtinen, V. (2021). The Good, the Bad and the Future: A SWOT Analysis of the Ecosystem Approach to Governance in the Baltic Sea Region. Sustainability, 13(19), 10539.

Jiskani, I. M., Shah, S. A. A., Qingxiang, C., Zhou, W., \& Lu, X. (2020). A multi-criteria based SWOT analysis of sustainable planning for mining and mineral industry in Pakistan. Arabian Journal of Geosciences, 13(21), 1-16.

Kayumovich, K. O., Alimovich, F. E., Khudoynazarovich, S. A., Shavkatovna, S. S., \& Supiyevna, B. M. (2020). Opportunities of mobile marketing in tourism. Journal of Critical Reviews, 7(12), 94-98.

Komari, A., Indrasari, L. D., Tripariyanto, A. Y., \& Rahayuningsih, S. (2020, July). Analysis of SWOT Marketing Strategies and 7P Influence on Purchasing Decision. In Journal of Physics: Conference Series (Vol. 1569, No. 3, p. 032002). IOP Publishing.

Landmann, E., Stolz-Römmermann, J., \& Günther, T. (2020). Customer Integration Through Virtual Reality Implementation: A SWOT Analysis in the Area of Production Systems. Progress in IS, 253-266.

Li, F., Larimo, J., \& Leonidou, L. C. (2021). Social media marketing strategy: definition, conceptualization, taxonomy, validation, and future agenda. Journal of the Academy of Marketing Science, 49(1), 51-70.

Li, C., Negnevitsky, M., \& Wang, X. (2020). Prospective assessment of methanol vehicles in China using FANP-SWOT analysis. Transport Policy, 96, 60-75.

Longhurst, G. J., Stone, D. M., Dulohery, K., Scully, D., Campbell, T., \& Smith, C. F. (2020). Strength, weakness, opportunity, threat (SWOT) analysis of the adaptations to anatomical education in the United Kingdom and Republic of Ireland in response to the Covid-19 pandemic. Anatomical sciences education, 13(3), 301-311. 
Putri, V. Y., Tasya, D. S., \& Rahayu, A. (2020). SWOT Analysis on Credit Guarantee Business Sector in Indonesia: A Study from Jamkrindo. Journal of Economics, Business and Management (JOEBM), 8(3), 151-156.

Rangkuti, H. A., Teruri, S., \& Shihab, M. R. (2020, October). The Roles of IT to Help An Organization Facing the Future: Case Study of the Television of the Republic of Indonesia. In 2020 International Conference on Information Technology Systems and Innovation (ICITSI) (pp. 85-88). IEEE.

Sari, S. N. (2020, August). Implementation of the Broadcasting Regulation as a Multicultural Communication Policy in Indonesia's Public Television Broadcasting Institution (LPP TVRI). In 2nd Jogjakarta Communication Conference (JCC 2020) (pp. 273-275). Atlantis Press.

Susanti, F., Jaswita, D. I., Nurwita, I. N., \& Fauziah, G. (2021, January). Improvement and Rejuvenation of Traditional Markets Based on SWOT Analysis in the City of South Tangerang. In The 1st International Conference on Research in Social Sciences and Humanities (ICoRSH 2020) (pp. 49-54). Atlantis Press.

Voukkali, I., \& Zorpas, A. A. (2022). Evaluation of urban metabolism assessment methods through SWOT analysis and analytical hierocracy process. Science of The Total Environment, 807, 150700. 